\title{
FACTORS AFFECTING E-SECURITY PERCEPTION IN TAXPAYERS' USE OF E-GOVERNMENT SYSTEM IN THE CITY OF ÇANAKKALE
}

\author{
Nazmi Y. YAĞANOĞLU 1 \\ Nilgün SERİM 2
}

\author{
Received Date (Başvuru Tarihi): \\ Accepted Date (Kabul Tarihi): \\ Published Date (Yayın Tarihi):
}

$12 / 05 / 2020$

$8 / 06 / 2020$

$25 / 06 / 2020$

In the article, the first author is in the role of Corresponding Author.

\begin{abstract}
This paper analyzes the factors that affect the perception of e-security in the use

Keywords:

E-government

Internet Usage

Trust

Ordered Probit

User Satisfaction

JEL Codes:

G18, L86, C26 of e-government system in Çanakkale using Ordered Probit model. Among these factors,
gender and age of the person do not have a significant effect on the level of trust to public institutions' websites. Those who have never been married have higher trust in the websites of public institutions. Compared to university graduates, primary and secondary school graduates and high school graduates have less trust in government agencies' websites, while graduate degree holders have higher trust. Trust is greater in those who think that the state will be more transparent with the development of e-government. According to the income level, it is understood that the people who earn 5001 TL and above are the most positive looking group in general. We also offer some policy advice to improve the confidence in and use of government websites: organizing awareness campaigns, focusing on ensuring the widespread use of the system for citizens aged 18-40, and requiring some public services to be carried out only through e-government.
\end{abstract}

\section{ÇANAKKALE İLINDE VERGİ MÜKELLEFLERİNİN E-DEVLET SİSTEMİ} KULLANIMINDA E-GÜVENLİK ALGISINI ETKİLEYEN FAKTÖRLER

ÖZ

\section{Anahtar Kelimeler: \\ E-Devlet}

Internet Kullanımı

Güven

Stralı Probit

Kullanıc Tatmini

JEL Kodları:

G18, L86, C26
Bu makale Çanakkale'de e-devlet sistemi kullanımında e-güvenlik algısını etkileyen faktörleri Sıralı Probit modeli ile araştırmaktadır. Çalışmada; Çanakkale'de edevlet sistemine adapte olmayı etkileyen demografik faktörlerden kişinin cinsiyetinin ve yaşının, kamu kurumlarının internet web sitelerine duyulan güven üzerinde anlamlı bir etkisinin olmadığı tespit edilmiştir. Hiç evlenmemiş olanlarda, evlilere göre kamu kurumlarının internet web sitelerine duyulan güven daha yüksektir. Eğitim düzeyi açısından bakıldığında, ilkokul ve ortaokul mezunlar ile lise ve dengi okul mezunlarının üniversite mezunlarına göre kamu kurumlarının internet web sitelerine duyduğu güven daha azdır. Lisansüstü eğitim alanların ise, üniversite mezunlarına kıyasla bu konuda duyduğu güven daha fazladır. E-devletin gelişmesiyle devletin daha şeffaf olacağın düşünenlerde güven daha fazladır. Gelir durumuna göre ise, 5001 TL ve üzerinde kazanan kişilerin genel olarak en olumlu bakan grup oldukları anlaşılmaktadır. E-devlet hizmetlerinin kullanımın öneren farkındalı kampanyaları düzenleyerek 18-40 yaş arasındaki vatandaşların sistemi yaygın kullanımını să̆lamaya odaklanmak, bazı kamu hizmetlerinin sadece e-devlet üzerinden yürütülmesini zorunlu hale getirmek hiç kuşkusuz sistemin kullanımını önemli ölçüde artıracaktır.

\footnotetext{
${ }^{1}$ Asst.Prof.Dr., Çanakkale Onsekiz Mart University, nazmiyagan@comu.edu.tr,

2 Emeritus Prof. Dr., Researcher, nserim@comu.edu.tr,
} 


\section{INTRODUCTION}

Since the turn of the millennium e-government concept and its applications have become part of our lives at an increasing rate. Governments started to offer online services to the citizens due to the advancements in communication technologies at the end of the 20th century. In time, these services increased in variety and volume. Traditional government approach required going to a public building to acquire information about, or to gain access to a public service. That setup limited the relationship between citizens and public institutions to a paperbased contact intermediated by public employees. On the other hand, e-government enables a citizen to upload information about himself/herself or download information of interest, thus personalizing the relationship at a lower cost.

E-government lets the state improve the efficiency of public service provided to citizens and firms, using tools of information technology. It helps carrying out activities such as purchases of goods and services by the government, informing the citizens about government activities and services quickly. Online services cut costs and improve efficiency. Public services are provided faster than traditional public institutions do. Thus, it benefits both the government and the citizen.

The funds spent for provision of e-government service have also increased over time. Similarly, the government has been collecting a larger part of taxes, fines and fees via internet now. Regardless of the expansion of e-government, its successful implementation depends on the acceptance of these services by the citizens. Citizens will be a part of the system only if they are convinced by the presentation of the e-government services.

It is important to increase the frequency of citizens'use of E-government applications. However, as the government tries to remove the citizens' lack of adoption to E-government applications, the sociological dimension of the issue should not be ignored. The success of E-government services depends on the voluntary use of them by the citizens. Lack of cohesion between E-government services and citizens prevents the expected benefits of the system. Every citizen expects to receive the taxes he/she has paid to be returned by the government as 
public services. Failure to provide services via E-government adequately means to the citizen that the taxes he/she paid have been wasted. Even simple problems with uploading/downloading documents online might lead to a perception of inefficiency. E-government technology contributes to productivity only if it can be used by the citizens

The views of citizens about E-government have been researched on many dimensions for about a couple decades now. In this study we focus on the factors that affect the adaptation of citizens to E-government services in the city of Çanakkale, Turkey. In this respect, our research question is "Which factors affect the e-security perception in the use of E-government system in Çanakkale?". The following section gives a brief survey of the related literature. Then we give information about our survey and data collection process, present our method of analysis, model and hypotheses. Then we analyze the data and discuss the results. Finally, we conclude and offer some policy advice.

\section{LITERATURE REVIEW}

Increasing internet usage and fast advancement of communication technologies encouraged governments to use these technologies in public services. They started converting their methods of offering public service from traditional bureucratic system into electronic structures that enable citizens to use web sites of public offices with a variety of electronic devices. By applying electronic service to governing procedures, governments expected to cut costs, increase quality in public sector and improve the performances of public institutions. They also aimed to decrease bureucracy by offering services online.

There are many models in the literature about technology adoption. However, two models come to the forefront in explaining the use of technology. The Technology Acceptance Model (TAM) developed by Davis (1989) and The Unified Theory of Acceptance and Use of Technology (UTAUT) created by Venkatesh et al. (2003) by selecting the appropriate structures from eight models (including TAM) related to technology acceptance. 
According to the TAM, the use of a technology is influenced by various factors. Most importantly, perceived ease of use and perceived usefulness of the technology offered determine whether there will be an intention to use the technology.

UTAUT attributes behavioral intention to use technology to performance expectancy, effort expectancy, social influence, voluntariness of use and demographic factors like age, gender and experience. Behavioral intention, together with facilitating conditions, explains the technology use. Researchers, for example, in different types of users, different types of organization, different types of technology, different time periods, etc. applied UTAUT to examine individual technology acceptance and used in various topics. They added new concepts to the model and expanded it. In the applications of this model, technology users are divided into different groups such as employees, consumers and citizens. An example is the application of UTAUT on taxpayers' filing of income tax (Carter \& Schaupp, 2008).

Risk perception and trust variables are also included in the extensions of UTAUT as new factors reflecting the thoughts of taxpayers in the e-taxation system (Hung, Chang and Yu (2006) and Schaupp, Carter and McBride (2010). The effect of trust on technology adoption had already been well established in other models (Warkentin et al.,2002)

As it is with almost any sort of human interaction, demographic factors are important in deciding whether people trust e-government enough to use online services. Colesca (2009) classifies them under "Preinteractional Factors" that are important in building trust. Previous studies on Turkish samples indicate a number of demographic factors as statistically significant in this context: sex and education level (Saruç, 2007), residence, educational level and occupation (Çelik \& Kabakuş, 2015). Educational level seems to be important according to both studies.

Institutional success depends on the quality of e-services provided. Protection of websites of the public institutions from hackers and keeping up with security updates are important for the quality of online services. The users will trust offered services, provided that their information is under protection. Users need to know 
that their personal information will not be used unethically and/or beyond the requirements of the service they are using. Thus, security can be considered to be the main element in offering public services online.

Many users of internet have fears of security, and this has become a research subject since consumer-to-consumer electronic trade began. In a paper on electronic trade security, trustworthiness is defined as "the perception of confidence in the electronic marketer's reliability and integrity ... This definition will facilitate the examination of the nature of the relationships among trustworthiness, privacy, security, and purchase intentions". (Bélanger et al., 2002:252)

Similarly, perception of honesty in matters of security and privacy affects citizens' decision to use E-government services. Citizens, despite believing that Egovernment can improve the way bureucracy works, might still be worried about sharing personal information with the government over internet. They might fear from the possibility of losing their privacy and that their information might be used illegally. In the last couple of decades, the issue of privacy and security has been widely discussed in papers about E-government. (GAO, 2001; Bélanger \& Hiller, 2006; Lean, Zailani, Ramayah, \& Fernando, 2009; Belanger and Crossler 2011; Smith et al. 2011) are a few examples. "Security is costly, but must be addressed in the design phase, as security breaches can shatter public trust in e-Government. Trust is a vitally important component of e-Government projects." (Reffat, R.M.,2003 :11).

According to the findings of a survey in Canada with 182 participants, people who already trust the government tend to strenghten their relationship using Egovernment. (Parent, Vandebeek, and Gemino,2005: 7) However, the same research has shown that the impact of e-government use on people with low confidence is insignificant. In another study using quantitative approach, a cross-sectional sample of 787 end users of US federal government service failed to prove that there is a relationship between the level of trust to the federal government and acceptance process of E-government. (Morgeson et al., 2011) Another survey data analyzed using the R Statistical Computing Environment from Australia and New Zealand to collect data from 500 respondents in each country. "Trust in government was found 
not to be correlated with trust in facets of e-government service provision but was associated with support for e-government investment. More intensive Internet users were more likely to trust e-government services" (Horsburgh et al., 2011:232)

According to Rehman et al (2012), the study of the e-government (using quantitative approach, online survey from 150 citizens in Pakistan) indicated that "perceived risk, trust in the internet, trust in the government, information security and transaction security are highly influential variables which influence the citizens' intention to adopt e-Ggovernment services to conduct transaction with the government websites." (Rehman et al.,2012:1)

A few articles focus on the decision of using E-government services and the efforts to improve citizens' attitude towards it (Zhang et al., 2014). Even though trust is an important factor in adaptation to E-government, technical problems in access to internet and lack of skills to use internet appear to be important obstacles before adaptation to the system that need to be taken into consideration. A survey, using quantitative approach, conducted at Abu-Shanab over 759 Jordanians revealed that trust in government, trust in technology, information quality, internet familiarity and privacy and security influence trust in e-government. (Abu-Shanab,2014:493-494)

According to some researchers, the effect of security appears to be indirect. According to this approach, citizens make their decision to embrace E-government depending on the type of the service they are using. In other words the type of the service affects citizens' choice of whether or not using E-government. (Al-adawi et al., 2005 :5) When they are using the E-government system, citizens expect that their personal information will be protected securely and used in integrity to increase user trust. The model is tested via a survey of 214 Singapore e-government web site users, Partial least squares (PLS) was used to analyze the data. The study also finds that "online trust is partly affected by the offline trust in the government. Hence, government agencies need to emphasize trust-building mechanisms in retaining users for their online public services (Teo et al., 2008: 99-132).

Perceived user friendliness is another factor that increases frequency of use. If the users do not perceive a website as helpful and easy to use, frequency of use 
decreaes. Even though user friendliness depends on the user, the more an Egovernment site is used, the better and more helpful it is. "All else being equal, the easier a system is to interact with, the less effort needed to operate it, and the more effort one can allocate to other activities contributing to overall job performance. (Davis, 1989:334)."

People who do not feel safe about the security of a website, if they are already not willing to use technology, might refrain from using online services that demand detailed personal information. Lallmahomed et al.'s (using Structural Equation Modelling, cross-sectional survey from 247 citizens in Mauritius) results show that performance expectancy and facilitating conditions are positively related to behavioural intention. They further investigate resistance to change in a pre-adoption stage and show that resistance to change and computer self-efficacy have a negative significant relationship with intention to use e-Goverment services. (Lallmahomed et al., 2017:68)

According to the findings of a survey of 529 participants from different regions of Turkey that focused on trust of internet and trust of government factors, analyzing the results with SEM (Structural Equation Modeling) technique, "performance expectancy, social influence, facilitating conditions and trust of internet were found to have a positive effect on behavioral intention to use egovernment services. Additionally, both trust factors were found to have a positive influence on Performance expectancy of e-government services, ... Effect of effort expectancy and trust of government were found insignificant on behavioral intention." (Kurfalı et al., 2017:168)

In recent years, we observe an increase in the number of similar studies which show that perceived effort expectancy and social influence affect the persistence in using E-government (Özkan and Kanat, 2011; Weerakkody et al., 2013; Lian, 2015, Abu-Shanab, 2017). Working on the adaptation of citizens to E-government enables the governments to understand the needs of the citizens better and helps them have success in improving online services. 
Another factor in reconstruction of government-citizen relationship via egovernment that helps increase the use of the system is creating different alternatives according to personal preferences. "Rather than providing services in a uniform way to all citizens, governments can use new technology to treat citizens as individuals and provide personalised services. Citizens become more in charge of their relationship with government and re-gain their trust and confidence in the public sector." (Reffat, R.M.,2003:3).

Transition to e-government brings forward transparency and accountability in public services. With e-government, the citizens tranform from a passive position into an active one which enables them to call the government to account, to seek their rights, to question where the government spends its money. Bannister \& Connolly urge for careful management of transparency. "Transparency may lead to defensive thinking and excessive caution-a return to the avoid-personal-risks-at-all-costs culture that new public management sought to eliminate." (Bannister \& Connolly, 2011:23).

The United Nations has been releasing reports of the "E-government Development Index (EGDI)" every other year, using three factors to calculate it: scope and quality of online services, telecommunication infrastructure, and the level of human capital. According to the United Nations E-Government Survey that was released in 2018 (the latest available for the moment) Turkey was classified as "High EGDI" meaning that the country has above average e-government development (United Nations, Department of Economic and Social Affairs, 2018: 232). Thus, it is more of a question of preferences and trust and less of a question of access to the use of e-government services for Turkey now.

\section{METHODOLOGY}

One of the models widely used in applied studies to analyze interrelations and interactions between opinion levels and demographic and socio-economic factors is the Ordered Probit. In our analysis, perceived trustworthiness, the dependent variable, is a discrete variable with five ordered levels of opinion ranging from Strongly agree to Strongly Disagree. The data to this variable is the answer to the 
question: "I trust making payments such as tax to government agencies online". Of course, the greatest risk here is the theft of personal information. If citizens use the websites of government agencies, we assume they do not perceive large risks associated with the activity. There are studies in the literature that analyze the factors that affect the element of trust in the presence of economic, social or political risk (economic trust, social trust, trust other nations, international trust (UN) using Probit analysis. Among the examples where such type of models are used in connection with trust are (Gine' et al. 2008; Akotey et al. 2011; Torgler, 2008; Dercon et al. 2011; Brewer, et al.2004 Uslaner, 2004). "Unlike other probit and logit models, the ordered probit model involves a qualitative dependent variable for which the categories have a natural order or ranking that reflects the magnitude of some underlying continuous variable/index." (Becker \& Kennedy, 1992: 127).

Since the dependent variable measuring trust in the goverment internet websites is used as an ordered discrete, we use the ordered probit model in our analysis. "The model assumes a linear effect of each independent variable as well as a series of break points between categories for the dependent variable. Maximum likelihood estimators are found for these parameters, along with their asymptotic sampling distributions, and an analogue of $R^{2}$ (the coefficient of determination in regression analysis) is defined to measure goodness of fit." (McKelvey \& Zavoina,1975:103).

A special case of the Probit estimation method, the Ordered Probit uses a categorical variable that has an order among the values that it can take. A typical example is a survey question with responses orderable according to Likert scale, which we use here. The model is estimated with a maximum likelihood process and the resulting coefficients are a bit tricky to interpret, since they are in standard normal variable terms. A more practical approach is converting these coefficients into marginal effects, i.e. the effect of a change in independent variable on the probability of a specific category of the dependent variable to come up. We have a dependent variable on 3-point Likert scale, so it is possible to examine the effects of each independent variable on each of these results to come up. To keep things simple and trackable, we will concentrate on the marginal effects on dependent variable 
taking value 3 , the highest positive answer.

Following are the hypotheses we are going to test in this study:

Table 1. Hypotheses

\begin{tabular}{|c|c|c|}
\hline Hypotheses & Related Question & Inference \\
\hline $\begin{array}{l}\text { H1 High level perception of benefit might be } \\
\text { positively related to the trust in the use of E- } \\
\text { government. }\end{array}$ & $\begin{array}{l}11, \\
33\end{array}$ & Perceived benefit \\
\hline $\begin{array}{l}\text { H2 High level perception of transparency might be } \\
\text { positively related to the trust in the use of E- } \\
\text { government. }\end{array}$ & 12 & Perceived transparency \\
\hline $\begin{array}{l}\text { H3 High level perception of efficiency and } \\
\text { productivity might be positively related to the trust in } \\
\text { the use of E-government }\end{array}$ & 13 & $\begin{array}{l}\text { Perceived efficiency and } \\
\text { productivity }\end{array}$ \\
\hline $\begin{array}{l}\text { H4 High level perception of communication speed } \\
\text { might be positively related to the trust in the use of E- } \\
\text { government }\end{array}$ & $\begin{array}{l}17 \\
29\end{array}$ & $\begin{array}{l}\text { Perceived communication } \\
\text { speed }\end{array}$ \\
\hline $\begin{array}{l}\text { H5 High level perception of decrease in problems with } \\
\text { the provision of services due to the use of e- } \\
\text { government might be positively related to the trust in } \\
\text { the use of E-government }\end{array}$ & 24 & $\begin{array}{l}\text { Perceived decrease in } \\
\text { problems with the provision } \\
\text { of services }\end{array}$ \\
\hline $\begin{array}{l}\text { H6 High level perception of education and compliance } \\
\text { problems of the administrative personnel might be } \\
\text { positively related to the trust in the use of E- } \\
\text { government }\end{array}$ & 26 & $\begin{array}{l}\text { Perceived education and } \\
\text { compliance problems related } \\
\text { to the administrative } \\
\text { personnel }\end{array}$ \\
\hline $\begin{array}{l}\text { H7 High level perception of persistence in provision of } \\
\text { services might be positively related to the trust in the } \\
\text { use of E-government }\end{array}$ & 30 & $\begin{array}{l}\text { Perceived persistence in } \\
\text { provision of services }\end{array}$ \\
\hline $\begin{array}{l}\text { H8 High level perception of image might be positively } \\
\text { related to the trust in the use of E-government }\end{array}$ & 32 & perceived image \\
\hline
\end{tabular}

Since the survey that provided our data was done at the end of 2017, it does not require a Research Ethics Committee approval since the data collected before 2020 are not subject to evaluation. 


\section{AN APPLICATION ON TAXPAYERS OF ÇANAKKALE}

The study was carried out by quantitative research method. In the study, we worked with a large-scale sample group, since we aimed to generalize the research findings to the research universe. Our aim was to reveal the cause and effect relationships among the social facts related to the subject we investigated through a statistical analysis of the social data that were converted into numerical values. Thus, it was aimed to contribute to a better understanding of the laws of the social order. The underlying survey was carried out in Çanakkale, Turkey in the third quarter of 2017. A sample of 975 taxpayers were given the questionnaire which had two groups of questions as well as the usual demographic ones: questions to measure role of egovernment in the relationship of the taxpayer and tax office and questions to measure general opinion about e-state system.

\subsection{Survey Sample}

This study is based on a survey on taxpayers of Çanakkale which is a relatively small city in northwestern Turkey. The sample consisted of a total of 975 participants including taxpayers of different professions (self-employed people, workers, government officials and shopkeepers) living in downtown Çanakkale. The sample does not include housewives, pensioners, unemployed people, or anyone subject to corporate taxes. 21 participants' data were not usable due to missing answers. Questions were asked to the subjects to measure role of e-government and e-state system in the relationship between the taxpayer and tax office. We used the method of simple random sampling from the taxpayer list. In general, the sample matches with the profile of the city in terms of the proportions of age, sex, education level, income level and marital status.

There were 42,431 taxpayers in the city at the time who were not subject to corporate tax. (G.İ.B,2018:165 and 167) This number is the population of the survey. Our net sample size of 954 taxpayers (975 minus 21 with missing data) is sufficient to make inference with $99 \%$ confidence level even under very conservative assumptions. 
Even though it is always possible that some of the participants might have given the "correct" answers for social recognition, we assume that all answers were given honestly. We made an effort to extract facts by asking different questions about the same topic and by using concrete variables such as justice of the taxes they paid, complexity of the tax legislation, knowledge of the fields of use of the taxes, etc.

\subsection{The Questionnaire and Analytical Method of the Survey}

The research was carried out with quantitative methods and the hypotheses mentioned in the previous section were tested, using a large scale sample. Quantitative data were collected from the sample and these data were analyzed statistically. Following this, the findings were generalized.

The questionnaire was prepared after a detailed literature review. The resulting questionnaire describes each scale with suitable headings for it. Cronbach's Alpha Factor, taking values from 0 to 1, shows the internal consistency of scales Cronbach's Alpha value was found as 0.8123 . 0.7 is regarded to be the lower limit to be considered a reliable scale, so we are good. (Kurtuluş, 2010:184), (Hair et.al., 2009: 265).

Since we had a variety of hypotheses to test, and since the questions were mostly of logical type, we decided to apply the survey (scanning) method as the most efficient one considering our resources, time being the scarcest. Questions of opinion were coded in 3-point Likert scale to keep the variety of answers under control. We asked 3 questions to identify the role of e-governance between the taxpayer and tax office, 18 questions to observe general opinion about e-state system, all 21 with 3point Likert scale. There were also seven questions of demographic nature, also coded at different details.

Survey was carried out asking questions face-to-face. As mentioned above we did not have any open ended questions in our questionnaire. Answers to all questions were coded for simplicity, either on 3-point Likert Scale or otherwise. Taxpayers were contacted and surveyed by interviewers who had prior training on this kind of activity. All participants were informed that the survey was for academical purposes, that their names would not be revealed since the analysis 
would be done collectively. This way we tried to convince them to be honest about their answers.

Survey data was entered and converted into MS Excel format. The rest of the analysis was done and tables were prepared using Stata. We used the ordered probit model to analysis effects of different covariates on the probability of having a positive attitude about e-government.

\subsection{Findings}

\subsubsection{Demographic Profile of the Participants}

Table 2 gives a summary of the demographic profile of the sample of analysis. We notice that nearly $79 \%$ of the sample are males. Although not ideal, considering the labor force participation rates in the country (roughly $37.5 \%$ for females and $80 \%$ for males) this is not too bad. Groups with highest frequency are: 31-40-year-old (age), married (marital status) high school graduates (education), tradesmanshopkeeper/commercial sector (profession), rents workplace (property ownership). Monthly income numbers are a little doubtful, and probably there is some underreporting here due to the survey being linked to taxes and government.

Table 2. Demographic Characteristics of the Taxpayers Who Constitute The Sample in the City of Çanakkale

\begin{tabular}{|c|c|c|c|c|c|c|c|c|c|c|c|}
\hline \multicolumn{2}{|c|}{ Demographics } & Freq.(n) & $\%$ & & & & & & & & \\
\hline \multicolumn{4}{|l|}{ Sex } & \multicolumn{4}{|c|}{ Education } & \multicolumn{4}{|l|}{ Property Owners } \\
\hline female & & 203 & 21,28 & \multicolumn{2}{|c|}{ Primary and/or secondary school } & 167 & 17,51 & Owns Home & & 230 & 24,11 \\
\hline \multirow[t]{2}{*}{ male } & & 751 & 78,72 & \multicolumn{2}{|c|}{ High School } & 422 & 44,23 & Owns workplace & & 31 & 3,25 \\
\hline & Total & 954 & 100 & \multicolumn{2}{|c|}{ University and Junior College } & 357 & 37,42 & \multicolumn{2}{|c|}{ Owns both home and workplace } & 139 & 14,57 \\
\hline \multicolumn{4}{|l|}{ Age } & \multicolumn{2}{|c|}{ Graduate (post-graduate, doctoral degr. \& med. spec.) } & 8 & 0,84 & Rents home & & 88 & 9,22 \\
\hline $18-30$ & & 189 & 19,81 & + & Total & 954 & 100 & Rents workplace & & 123 & 12,89 \\
\hline $31-40$ & & 414 & 43,4 & \multicolumn{2}{|c|}{ Profession } & & & \multicolumn{2}{|c|}{ Rents both home and workplace } & 343 & 35,95 \\
\hline $41-60$ & & 315 & 33,02 & \multicolumn{2}{|c|}{ Worker(skilled-unskilled) } & 66 & 6,92 & & Total & 954 & 100 \\
\hline \multirow[t]{2}{*}{$61+$} & & 36 & 3,77 & Official & & 19 & 1,99 & Monthly Income & & & \\
\hline & Total & 954 & 100 & \multicolumn{2}{|c|}{ Tradesman/shopkeeper/commercial } & 745 & 78,09 & (1000TL or less) & & 96 & 10,06 \\
\hline \multicolumn{4}{|c|}{ Marital Status } & \multicolumn{2}{|c|}{ Professional Occupation } & 41 & 4,3 & (1001TL-2000TL) & & 332 & 34,8 \\
\hline \multicolumn{2}{|c|}{ never married } & 193 & 20,23 & Other & & 83 & 8,7 & (2001TL-3000TL) & & 298 & 31,24 \\
\hline married & & 699 & 73,27 & & Total & 954 & 100 & (3001-4000 TL) & & 108 & 11,32 \\
\hline divorced & & 47 & 4,93 & & & & & $(4001-5000 T L)$ & & 61 & 6,39 \\
\hline \multirow[t]{2}{*}{\begin{tabular}{|l|} 
widow(spo \\
use dead)
\end{tabular}} & & 15 & 1,57 & & & & & $(5001 \mathrm{TL}+)$ & & 59 & 6,18 \\
\hline & Total & 954 & 100 & & & & & & Total & 954 & 100 \\
\hline
\end{tabular}


Figure 1 gives a summary of internet usage frequencies of the participants. Nearly $90 \%$ of the sample uses internet with different intervals. $9.3 \%$ report they never use it. $41.54 \%$ use the internet frequently.

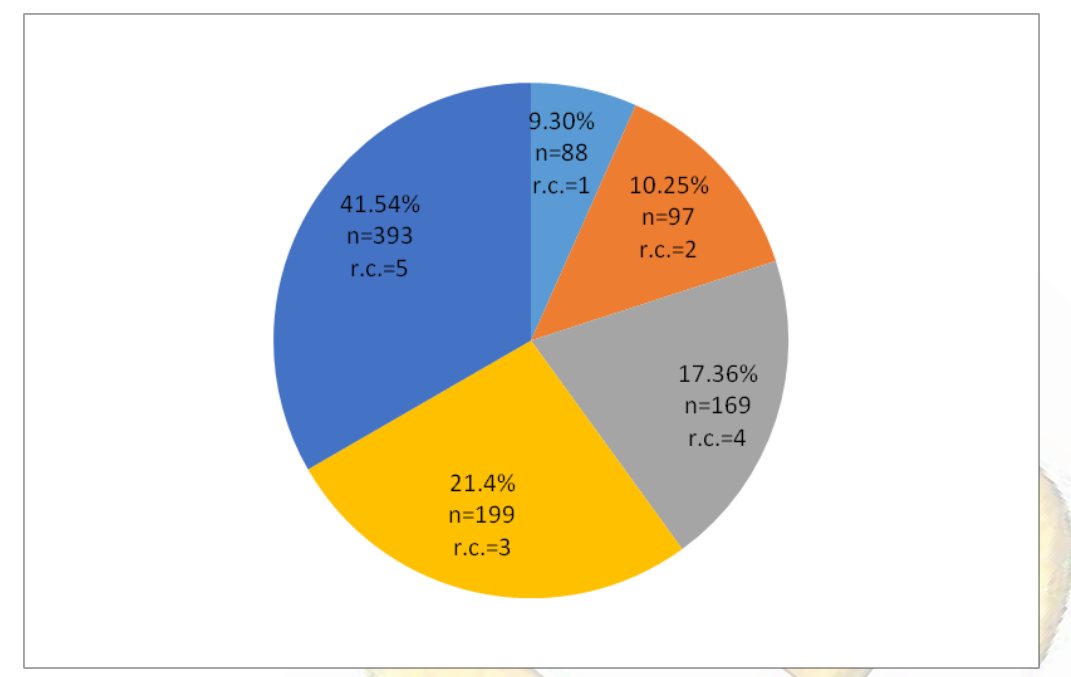

Figure 1. Frequency of the Use of Internet by Taxpayers

Reply Chic (r.c.): every day (5), a few days a week (4), a few days a month (3), rarely (2), never (1). 8 partic

\subsubsection{Findings of Ordered Probit Analysis}

All questions except age, sex, education, profession, marital status, monthly income and property ownership were formulized according to 3-point Likert scale. While converting the answers into data, we decided to code them as 1,2 and 3 , corresponding to "I do not agree", "I neither agree nor do not agree" and "I agree" in that order, higher value corresponding to more positive answer.

The independent variables list includes, aside from the usual demographic factors, include demographic factors, questions about taxpayer opinion under eight main headings expected to affect the dependent variable.These are questions 11,33 (about the usefulness of online government services), question 12 (about government being more transparent with e-government), question 13 (Government becoming more efficient and effective with the development of e-government), questions 17,29 (e-government applications have made services faster), question 24 (e-government decreases problems in provision of public services), question 26 (seeing the problem 
of education and non-compliance of working staff as the biggest obstacle to egovernment applications), question 30 (with e-government applications, efficiency increased in provision of services), question 32 (web sites of public institutions are good).

In this study, dependent variable is the 3-point Likert scaled response to the expression "I trust government offices enough to make online payments for taxes etc." It is a 3-point Likert scaled variable with 1 the most negative and 3 the most positive response. Reference group: male, 31-40 years, married, with undegraduate degree from college, government official (full-time employee), home owner, salary TRY 2001-3000. Marginal effects are calculated only for the highest category of the dependent variable, in other words they represent the effects of covariates on the probability of dependent variable being equal to 3 , the highest level of trust.

Since the tables 3-14 take a lot of space and make it very hard to keep a wellordered page, we present them at the end of the paper

The number of independent variables in the basic demographic model (Table 3 ) is 24; some are statistically significant and some are not. Each of the following tables adds one question from the survey to the demographic model and reveals results. Since it would take a tremendous amount of space to show coefficients and marginal effects of all variables in all tables, we only show the ones that are statistically significant or closer to being significant.

-Table 3 shows the estimated probit coefficients, corresponding marginal effects and p-values for model 1. Here the dependent variable is based on the responses to the expression "I have confidence to make online payments for taxes etc. to government agencies (Q.34)". The variables for age, sex, profession, ownership status and monthly income all fail to show significant marginal effects. On the other hand, marital status and educational level make a difference. These findings show that some social trends might be changing. A decade ago another study, using ordinary least squares regression analysis, found significant coefficients for sex and educational level, while income and age did not seem to affect the use of egovernment (Saruç, 2007: 210-211). Reserving any bias that might be caused by 
sampling and methodological differences, demographic factors might not be as important as they were a decade ago in citizens' attitude and trust towards egovernment. Other things being constant, an unmarried person's probability to have confidence to make online payments to government agencies is $34 \%$ less than a married person's. Education estimates reveal that there is a positive relationship between confidence to make payments and educational level. People with a graduate degree differ from the reference group (undergraduate college degree) with a positive marginal effect while lower education levels have negative signs, showing that they are less likely to have confidence to make online payments.

-Model 2 at Table 4 has an additional variable to the model 1 at table 4 : Question 11 which asks for response to the expression "In the functioning of the state, I find the e-government positive (the citizen's exchange of information and services with the state via the internet)". When the value of this variable increases, in other words when the opinion is more positive, the probability of having confidence to make online payments increases too, by an average of $18.7 \%$ per point.

-Model 3 at Table 5 has an additional variable to the model 1 at table 4: Question 12 which asks for response to the expression "I think the state will be more transparent with the development of e-government". We can conclude that as the opinion moves towards more transparency of government via e-government, the possibility of high confidence in making online payments to the government increases. The marginal effect is $21.35 \%$ and significant at $5 \%$ level.

- Model 4 at Table 6 has an additional variable to the model 1 at table 4 : Question 13 which asks for response to the expression "I think the state will be more effective and efficient with the development of e-government". According to the marginal effect estimates, a more positive opinion about government to become more efficient and effective due to e-government increases the probability of having more confidence in government to make online payments. The marginal effect is statistically significant at $10 \%$ level.

- Model 5 at Table 7 has an additional variable to the model 1 at table 4: Question 17 which asks for response to the expression "Thanks to the use of e- 
Government system, communication with the tax administration is faster". As the participant opinion about faster communication becomes more positive, the possibility of feeling confident in making online payments to the government increases by a margin of $34.17 \%$, statistically significant at 10 percent level.

- Model 6 at Table 8 has an additional variable to the model 1 at table 4: Question 21 which asks for response to the expression "I think the E-Government System has increased the efficiency and speed in providing services". If a taxpayer thinks more positively about this expression, the probability of having confidence in making online payments to the government increases. The marginal effect is $36.89 \%$ per point, statistically significant at $5 \%$ level.

- Model 7 at Table 9 has an additional variable to the model 1 at table 4 : Question 24 which asks for response to the expression "E-government applications reduced the disruptions in the delivery of public services.". Results show a positive relationship between the perception that problems in using public services have become fewer due to e-governement applications and the confidence to make payments online to the government. The marginal effect is $43.5 \%$ and significant.

- Model 8 at Table 10 has an additional variable to the model 1 at table 4: Question 26 which asks for response to the expression "The problem of training and non-compliance of the working staff is the biggest obstacle to e-government applications". People who think that education and compliance problems of the government officers are the biggest obstacles before e-government applications are more likely to feel confident about making online payments to the government. The marginal effect is $20.77 \%$ and statistically significant.

- Model 9 at Table 11 has an additional variable to the model 1 at table 4: Question 29 which asks for response to the expression "Speed increases in the provision of government services with E-government applications". People who have a more positive approach to the expression are more likely to have confidence to make online payments to the government. The marginal effect is about $40.25 \%$ and statistically significant. 
- Model 10 at Table 12 has an additional variable to the model 1 at table 4: Question 30 which asks for response to the expression "E-government applications increase efficiency in the provision of government services". People who approach this expression more positively are more likely to have confidence to make online tax payments etc. Marginal effect is $40.14 \%$ and statistically significant.

-Model 11 at Table 13 has an additional variable to the model 1 at table 4: Question 32 which asks for response to the expression "I generally find the websites of the official institutions I visit very good.". People who have a positive impression of government agencies' web pages are more likely to have confidence to make online payments to the government. Marginal effect is $48.45 \%$ and statistically significant.

-Model 12 at Table 14 has an additional variable to the model 1 at table 4: Question 33 which asks for response to the expression "I think online government services (for example, tax returns on the internet) are useful". According to the estimates, people who have a positive view about online government services being useful are more likely to have confidence to make payments such as taxes online. The marginal effect is $44.69 \%$ and significant.

Some interesting points are:

-The hypotheses listed in Table 1 have all been supported by our data at least at $10 \%$ significance level. These hypotheses are closely related to the theories of technology adoption that we mentioned earlier. Perceived benefit (usefulness), perceived transparency, perceived efficiency and productivity, perceived communication speed, perceived persistence in provision of services, perceived education and compliance problems related to the administrative personel, perceived persistence in provision of services and perceived image all have positive effects on citizens' trust in e-government.

-18-30 age group seems to have a more positive attitude towards egovernment, while the participants aged 61 and higher are the most negative group.

-Unmarried participants have more negative view compared to others.

-According to educational level, the most negative attitude towards online 
payment of taxes is shown by primary school graduates. As a matter of fact, as the educational degree gets higher, the attitude gets more positive.

-Among different professions, the most negative opinion belongs to traders/artisans. - Participants who pay rent for both living quarters and workplace tend to think more positively than other property ownership categories.

-From income point of view, those who make TL 5001 or more a month have a more positive approach than the others.

\section{CONCLUSION AND FUTURE REMARKS}

Since e-government has been used as a service delivery method, a lot of research has been done to find out what are the most important factors affecting citizen satisfaction and the success of e-government services. The need for trust and the importance of trust are emphasized in the research literature to adapt and use egovernment system successfully. Studies investigating trust in e-government generally conducted their research on the concepts of trust in technology and trust in the state. Government agencies factor, the risks posed by e-government systems and citizens' perception of e-government are less explored. When the studies on the literature are generally evaluated; the risk perceived by the user regarding the website, the control perceived about the website and the opinion about the internet are effective on the adaptation to the e-government system. If citizens perceive the design of the website as easy to use and useful for themselves it becomes easier to adapt to the e-government system. It can be said that the quality of the service provided creates satisfaction and helps with the adaptation to the e-government system. In this study, factors affecting the confidence in the system were investigated, considering the importance of trust in the adaptation to the egovernment system in Çanakkale. Research model investigated the perception factors (benefit, transparency, efficiency and effectivity, communication speed, continuity / disruption in service delivery, image). It has been revealed that these eight factors were significantly effective in adapting to the e-government system. Those who think that the state will be more transparent, more effective, faster and more efficient with the development of e-government are more comfortable in 
relying on confidence in government offices when making payments over the internet. Those who think that their communication with the tax administration has become faster thanks to the use of the e-Government system, that the e-Government system increases the efficiency and speed in service delivery, and that it reduces the disruptions in the provision of public services, they feel safe when paying online. Those who consider the training of employee personnel and the problem of not adapting to technology as the biggest obstacle before e-government applications, feel more secure when making payments to public offices over the internet. Those who think that online government services are useful, those who find the websites of government agencies they visited generally very good perform their transactions with greater confidence through these sites.

Higher efficiency expectations from the system than traditional government departments, such as being accessible from the system quickly and at any time, affects the choice of using the system positively. The presence of conditions that facilitate the use of the system, such as the user-friendly interface, is another factor that will positively affect the user choice to use the system. Education, advertising and promotional campaigns etc. Thanks to education, advertisement and promotion campaigns etc., perceived awareness about the system can be increased and the behavior of using the system can be positively affected. Another factor that adversely affects the use of e-government services is the intention to use them in the future and to postpone the use of this system. In particular, citizens with a lack of self-efficacy in computer use may be encouraged to attend free computer courses offered by district municipalities, and this problem can be solved. Thus, the workload of public personnel can be reduced by preventing citizens from continuing their desire to receive services by going to traditional government offices.

According to the United Nations' EGDI numbers that we mentioned earlier, Turkey has high scores in 2 out of 3 components of the index in 2018: 0.8889 in "online service component" and 0.8148 in "human capital component" (out of 1) . These are the numbers compatible with very high EGDI, top 40 countries. The reason Turkey is not within that group is the "telecommunication infrastructure 
component" valued at 0.4298 . It seems to be a high priority task to improve the infrastructure for improvement in e-government.

It is obvious that the factor of trust in adapting to the e-government system is a factor that will affect the future of the e-government system. This study can be a reference for better understanding of the problems regarding adaptation to the egovernment system and future studies. It is also thought that this study will contribute to the literature that includes studies on trust and the development of egovernment policies. The conclusions will help decision-makers in the state system to review the disadvantages of the e-government system, revise it, and convince more citizens to reach and use the system through the e-government system. Future research could also further extend the model with the addition of perceived awareness and trust in Internet and trust in government as independent predictors. 


\section{REFERENCES}

Abu-Shanab, E. (2014). Antecedents of trust in E-government services: An empirical test in Jordan. Transforming Government: People, Process and Policy, 8(4), 480-499.

Abu-Shanab, E.A. (2017). E-government familiarity influence on Jordanians' perceptions, Telematics and Informatics, Vol. 34, No. 1, pp.103-113.

Akotey OJ, Osei KA, Gemegah A (2011) The Demand For Micro İnsurance İn Ghana. The Journal of Risk Finance, 12:182-194.

Al-adawi, Z., Yousafzai, S. and Pallister, J. (2005). Conceptual Model Of Citizen Adoption Of EGovernment, Proceedings of the Second International Conference on Innovations in Information Technology (IIT'05), 1-10

Bannister, F. and Connolly, R. (2011). The Trouble with Transparency: A Critical Review of Openness in e-Government. Policy and Internet. 3(1), 1-30

Becker, W. E. and P. E. Kennedy, (1992). A Graphical Exposition of the Ordered Probit, Econometric Theory. 8 (1), 127-131.

Belanger, F., and Crossler, R.E. (2011). Privacy in the Digital Age: A Review of Information Privacy Research in Information Systems, MIS Quarterly,35(4), 1017-1041

Bélanger, F. \& Hiller, J. (2006) A Framework For E-Government: Privacy İmplications. Business Process Management Journal, 12(1),48-60

Brewer, Paul R., Kimberly Gross, Sean Aday and Lars Willnat (2004). International Trust and Public Opinion about World Affairs, American Journal of Political Science. 48(1), 93-109.

Carter, L., and Schaupp, L. C. (2008). Efficacy And Acceptance İn E-File Adoption. In Proceedings of the 14th Americas Conference on Information Systems (pp. 1-11).

Colesca, S.E. (2009). Understanding Trust in E-Government. Engineering Economics. (3), 7-15.

Çelik, A. K., and Kabakuş, A. K. (2015). Do E-government Services 'Really' Make Life Easier? Analyzing Demographic Indicators of Turkish Citizens' E-government Perception Using Ordered Response Models. Mediterranean Journal of Social Sciences, 6(1), 185-194

Davis, F. (1989) Perceived Usefulness, Perceived Ease Of Use And User Acceptance Of İnformation Technology. MIS Quarterly, 13(3), 319-340.

Dercon S, Gunning J, Zeitlin A (2011) The Demand For Insurance Under Limited Trust: Evidence From A Field Experiment In Kenya. University of Wisconsin, Agriculture and Applied Economics, Madison.

GAO (General Accounting Office), McClure, D. (2001) Electronic Government: Challenges Must Be Addressed With Effective Leadership And Management. https://www.gao.gov/new.items/d01959t.pdf ( Accessed,14 November 2019)

Gine' X, Townsend R, Vickery J (2008). Patterns Of Rainfall İnsurance Participation İn Rural India. World Bank Economic Review,22(3),539-566.

Hair, J. F.. Anderson, R. E. , Tatham, R. L., Black, W. C. (2009). Multivariate Data Analysis, Prentice Hall, New Jersey.

Horsburgh, S., Goldfinch, S. and Gauld, R. (2011). Is Public Trust İn Government Associated With Trust İn E-Government?", Social Science Computer Review, 29 (2), 232-241.

Hung, S.Y., Chang, C.M, and Yu, T.J., Determinants Of User Acceptance Of The E-Government Services: The Case Of Online Tax Filing And Payment System, Government Information Quarterly, 23, 2006.

Kurfalı, M., Arifoğlu, A., Tokdemir, G. and Paçin, Y. (2017). Adoption of e-government services in Turkey', Computers in Human Behavior, 66(1), 168-178.

Kurtuluş, K. (2010). Araştırma Yöntemleri, İstanbul,Türkmen Kitabevi. 
Lallmahomed M. Z., Lallmahomed N., and Lallmahomed G. M., (2017). Factors İnfluencing The Adoption Of E-Government Services İn Mauritius, Telematics and Informatics, 34(4), 57-72

Lean, O. K., Zailani, S., Ramayah, T., \& Fernando, Y. (2009). Factors İnfluencing İntention To Use EGovernment Services Among Citizens In Malaysia. International Journal of Information Management, 29(6), 458-475.

Lian, J-W. (2015) .Critical Factors For Cloud Based E-İnvoice Service Adoption İn Taiwan: An Empirical Study, International Journal of Information Management, 35( 1),98-109.

McKelvey, R.D. \& W. Zavoina. (1975). A Statistical Model For The Analysis Of Ordinal Level Dependent Variables. Journal of Mathematical Sociology, 4(1), 103-120.

Morgeson, Forrest V., III, David Van Amburg, and Sunil Mithas. (2011). Misplaced Trust? Exploring the Structural of the E-Government-Citizen Trust Relationship. Journal of Public Administration Research and Theory,21(2),257-83.

Özkan, S., Kanat, I.E., (2011). E-Government Adoption Model Based On Theory Of Planned Behavior:Empirical Validation, Government Information Quarterly, 28 (4), 503-513.

Parent,M., Vandebeek, C., \& Gemino, A. (2005). Building Citizen Trust Through E-Government. Government Information Quarterly, 22(4), 720-736.

Reffat, R.M.(2003).Developing a Successful E-Government, (Working Paper): University Of Sydney, Australia.

Rehman, M., Kamal, M., \& Esichaikul, V. (2012). Determinants Of Trust İn E-Government Adoption: A Case Study Of Pakistan. AMCIS Proceedings 12,1-10.

Saruç, N.T. (2007). E-Devlet Hizmetlerinden Yararlanma Derecesi ve Algilanan Hizmet Kalitesi: Amprik Bir Çalışma. Afyon Kocatepe Üniversitesi İIBF Dergisi, 9(1), 191-213.

Schaupp, L.C., Carter, L. and McBride M..E. (2010)."E-File Adoption: A Study Of U.S. Taxpayers' Intentions". Computers in Human Behavior, 26(4), 636-644

Smith, H.J., Dinev, T., and Xu, H. (2011). Information Privacy Research: An Interdisciplinary Review, MIS Quarterly, 35(4), 989-1015.

Teo, T.S.H., Srivastava, S.C. and Jiang, L. (2008). Trust And Electronic Government Success: An Empirical Study, Journal of Management Information Systems, 25(3), 99-132.

Torgler, B. (2008). Trust İn İnternational Organizations: An Empirical İnvestigation Focusing On The United Nations. Review of International Organizations, 3(1), 65-93.

United Nations. Department of Economic and Social Affairs (2018). E-Government Survey 2018. https://publicadministration.un.org/en/Research/UN-e-Government-Surveys

Uslaner, E. M. (2004). Trust, Civic Engagement, And The Internet. Political Communication, 21(2), 223242

Venkatesh, V., Morris, M.G., Davis, G.B. and Davis, F.D. (2003). User Acceptance Of İnformation Technology: Toward A Unified View. MIS Quarterly, 27(3), 425-478

Warkentin, M., Gefen, D. Pavlou, P.A and Rose, G.M (2002) Encouraging Citizen Adoption to EGovernment by Building Trust. Electronic Markets 12 (3), 157-162

Weerakkody, V., El-Haddadeh, R., Al-Sobhi, F., Shareef, M.A. and Dwivedi, Y.K. (2013) 'Examining The İnfluence Of İntermediaries İn Facilitating E-Government Adoption: An Empirical İnvestigation', International Journal of Information Management, 33( 5),716-725.

Zhang, H., Xu, X., Xiao, J., (2014). Diffusion Of E-Government: A Literature Review And Directions For Future Directions. Government Information Quarterly, 31 (4), 631-636. 


\section{Appendix: Tables 3-14}

Table 3

\begin{tabular}{|c|c|c|}
\hline & \multicolumn{2}{|c|}{ Model } \\
\hline & \multicolumn{2}{|c|}{1} \\
\hline Variables & Coef. & p-val. \\
\hline $18-30$ & .309483 & 0.019 \\
\hline \multicolumn{3}{|l|}{ Marital Status } \\
\hline Never Married & -.8982793 & 0.000 \\
\hline \multicolumn{3}{|l|}{ Education Level } \\
\hline primary and/or secondary & -.7522004 & 0.000 \\
\hline high school & -.3824159 & 0.001 \\
\hline graduate degree & 3.830 & 0.978 \\
\hline \multicolumn{3}{|l|}{ Profession } \\
\hline tradesman/artisan & -.6249102 & 0.047 \\
\hline \multicolumn{3}{|l|}{ Ownership Status } \\
\hline Paying rent for workplace & .2923533 & 0.049 \\
\hline Payin rent for both & .28777 & 0.012 \\
\hline \multicolumn{3}{|l|}{ Monthly Income } \\
\hline (1000TL or less) & .1058687 & 0.506 \\
\hline (1001TL-2000TL) & -.2133276 & 0.046 \\
\hline$(5001 \mathrm{TL}+)$ & .4585169 & 0.029 \\
\hline
\end{tabular}

Table 4

\begin{tabular}{|c|c|c|}
\hline Regressions & \multicolumn{2}{|c|}{ Model } \\
\hline Q.11 & \multicolumn{2}{|c|}{2} \\
\hline Variables & Coef. & p-val. \\
\hline \multicolumn{3}{|l|}{ Age } \\
\hline $18-30$ & .2579259 & 0.053 \\
\hline \multicolumn{3}{|l|}{ Marital Status } \\
\hline Never Married & -.9562799 & 0.000 \\
\hline \multicolumn{3}{|l|}{ Education Level } \\
\hline Primary and/or seco & -.8730423 & 0.000 \\
\hline High School & -.5124787 & 0.000 \\
\hline Graduate Degree & 3.623568 & 0.981 \\
\hline \multicolumn{3}{|l|}{ Profession } \\
\hline Tradesman/artisan & -.7788933 & 0.011 \\
\hline Other & -.6119245 & 0.082 \\
\hline \multicolumn{3}{|c|}{ Ownership of home/workplace } \\
\hline Rents workplace & .5720619 & 0.000 \\
\hline Rents both & .2752678 & 0.018 \\
\hline \multicolumn{3}{|l|}{ Monthly Income } \\
\hline$(5001 \mathrm{TL}+)$ & .5774231 & 0.009 \\
\hline Question 11 & .5230423 & 0.000 \\
\hline
\end{tabular}

\begin{tabular}{|l|c|l|}
\hline Q.11 & \multicolumn{2}{|c|}{2} \\
\hline Marginal Effects & Marg. & $p$-val. \\
\hline Variables & & \\
\hline Age & & \\
\hline 18 -30 & .0885031 & 0.208 \\
\hline Marital Status & & \\
\hline Never Married & -.3619253 & 0.000 \\
\hline Education Level & & \\
\hline Primary and/or sece & -.3323144 & 0.000 \\
\hline High School & -.1839492 & 0.066 \\
\hline Graduate Degree & .3298889 & 0.000 \\
\hline Profession & & \\
\hline Tradesman/artisan & -.2426358 & 0.220 \\
\hline Other & -.2350985 & 0.115 \\
\hline Ownership of home/workplace \\
\hline Rents workplace & .1798851 & 0.207 \\
\hline Rents both & .0963442 & 0.159 \\
\hline Monthly Income & & \\
\hline (5001 TL+) & .1766301 & 0.245 \\
\hline Question 11 & .1870771 & 0.070 \\
\hline
\end{tabular}


Table 5

Regressions
\begin{tabular}{|l|l|l|}
\hline Q.12 & \multicolumn{2}{|c|}{3} \\
\hline Variables & Coef. & p-val. \\
\hline Age & & \\
\hline $18-30$ & .3899877 & 0.004 \\
\hline Marital Status & & \\
\hline Never Married & $-1,004,483$ & 0.000 \\
\hline Widow & .7642954 & 0.033 \\
\hline Education Level & & \\
\hline Primary and/or ss & -.6752412 & 0.000 \\
\hline High School & -.484086 & 0.000 \\
\hline Graduate Degree & 3.487077 & 0.979 \\
\hline Profession & & \\
\hline Tradesman/artis & -.6741234 & 0.053 \\
\hline Ownership of home/workplace & \\
\hline Rents workplace & .5250013 & 0.001 \\
\hline Rents both & .3143921 & 0.008 \\
\hline Monthly Income & & \\
\hline (5001 TL+) & .733656 & 0.001 \\
\hline Question 12 & .5999756 & 0.000 \\
\hline
\end{tabular}

\begin{tabular}{|l|c|c|}
\hline & \multicolumn{2}{|c|}{3} \\
\hline Marginal Effects & \multicolumn{2}{|c|}{$p$-val. } \\
\hline Variables & Marg. & \\
\hline Age & & \\
\hline $\mathbf{1 8 - 3 0}$ & .12978 & 0.143 \\
\hline Marital Status & & \\
\hline Never Married & -.37917 & 0.000 \\
\hline Widow & .2114055 & 0.260 \\
\hline Education Level & & \\
\hline Primary and/or s & -.25598 & 0.003 \\
\hline High School & -.172865 & 0.053 \\
\hline Graduate Degree & .325783 & 0.000 \\
\hline Profession & & \\
\hline Tradesman/artis & -.21305 & 0.207 \\
\hline Ownership of home/workplace \\
\hline Rents workplace & .16585 & 0.165 \\
\hline Rents both & .109033 & 0.120 \\
\hline Monthly Income & & \\
\hline (5001 TL+) & .2111445 & 0.219 \\
\hline Question 12 & .2135295 & 0.045 \\
\hline
\end{tabular}

Table 6

Regressions
\begin{tabular}{|l|l|l|}
\hline Q.13 & \multicolumn{2}{|c|}{4} \\
\hline Variables & Coef. & p-val. \\
\hline Age & & \\
\hline 18-30 & .3381113 & 0.013 \\
\hline Marital Status & & \\
\hline Never Married & -.9274721 & 0.000 \\
\hline Widow & .8139612 & 0.025 \\
\hline Education Level & & \\
\hline Primary and/or & -.6413527 & 0.000 \\
\hline High School & -.4466709 & 0.000 \\
\hline Graduate Degre & 3.362821 & 0.982 \\
\hline Profession & & \\
\hline Tradesman/artis & -.8581669 & 0.015 \\
\hline Ownership of home/workplace \\
\hline Rents workplace & .5529554 & \\
\hline Rents both & .3538684 & 0.003 \\
\hline Monthly Income & \\
\hline (1001TL-2000TL & -.263223 & 0.018 \\
\hline (5001 TL+) & .6340764 & 0.005 \\
\hline Question 13 & .6776442 & 0.001 \\
\hline
\end{tabular}

\begin{tabular}{|l|c|c|}
\hline Rsm.Drlr.intrnt.ue & \multicolumn{2}{|c|}{4} \\
\hline Marginal Effects & \multicolumn{2}{|c|}{ p-val. } \\
\hline Variables & Marg. & \\
\hline Age & & \\
\hline 18-30 & .1135348 & 0.189 \\
\hline Marital Status & & \\
\hline Never Married & -.350482 & 0.000 \\
\hline Widow & .220288 & 0.314 \\
\hline Education Level & & \\
\hline Primary and/or se & -.2428402 & 0.009 \\
\hline High School & -.1595762 & 0.084 \\
\hline Graduate Degree & .3248188 & 0.000 \\
\hline Profession & & \\
\hline Tradesman/artisar & -.26065 & 0.236 \\
\hline Ownership of home/workplace \\
\hline Rents workplace & .1733963 & 0.212 \\
\hline Rents both & .1221953 & 0.143 \\
\hline Monthly Income & \multicolumn{2}{|l|}{} \\
\hline (1001TL-2000TL) & -.0951848 & 0.129 \\
\hline (5001 TL+) & .1886832 & 0.258 \\
\hline Question 13 & .2410045 & 0.073 \\
\hline
\end{tabular}




\section{Table 7}

\begin{tabular}{|l|l|l|}
\hline Age & & \\
\hline $18-30$ & .2583248 & 0.072 \\
\hline $61+$ & -.7424569 & 0.003 \\
\hline Marital Status & & \\
\hline Never Married & -.9204104 & 0.000 \\
\hline Widow & .9990249 & 0.018 \\
\hline Education Level & & \\
\hline Primary and/or secor & -.5680299 & 0.000 \\
\hline High School & -.2852604 & 0.019 \\
\hline Graduate Degree & 3.23202 & 0.983 \\
\hline Profession & & \\
\hline Tradesman/artisan & -.6081221 & 0.098 \\
\hline Ownership of home and workplace \\
\hline Renting workplace & .4488045 & 0.004 \\
\hline Renting both & .3499264 & 0.004 \\
\hline Monthly Income & & \\
\hline (1001TL-2000TL) & -.2081599 & 0.070 \\
\hline (5001 TL+) & .5507276 & 0.021 \\
\hline Question 17 & .9719108 & 0.000 \\
\hline
\end{tabular}

\begin{tabular}{|l|l|l|}
\hline \multicolumn{2}{|l|}{ Age } & \\
\hline $18-30$ & .0869137 & 0.238 \\
\hline $61+$ & -.286095 & 0.009 \\
\hline Marital Status & \\
\hline Never Married & -.346251 & 0.000 \\
\hline Widow & .2446541 & 0.349 \\
\hline Education Level & \\
\hline Primary and/or second & -.212931 & 0.028 \\
\hline High School & -.100806 & 0.153 \\
\hline Graduate Degree & .3161906 & 0.000 \\
\hline Profession & \\
\hline Tradesman/artisan & -.192007 & 0.274 \\
\hline Ownership of home and workplace & \\
\hline Renting workplace & .1425281 & 0.219 \\
\hline Renting both & .1193979 & 0.160 \\
\hline Monthly Income & \\
\hline (1001TL-2000TL) & -.074267 & 0.197 \\
\hline (5001 TL+) & .1657851 & 0.268 \\
\hline Question 17 & .3417758 & 0.085 \\
\hline
\end{tabular}

Table 8

\begin{tabular}{|c|c|c|}
\hline \multirow{2}{*}{$\begin{array}{l}\text { Regressions } \\
\text { Q.21 }\end{array}$} & \multicolumn{2}{|c|}{ Model } \\
\hline & \multicolumn{2}{|c|}{6} \\
\hline Variables & Coef. & $p$-val. \\
\hline \multicolumn{3}{|l|}{ Age } \\
\hline $61+$ & -.9123141 & 0.000 \\
\hline \multicolumn{3}{|l|}{ Marital Status } \\
\hline Never Married & -1.072067 & 0.000 \\
\hline Divorced & .5835545 & 0.053 \\
\hline Widow & 1.205634 & 0.005 \\
\hline \multicolumn{3}{|l|}{ Education Level } \\
\hline Primary and/or Se & -.7443954 & 0.000 \\
\hline High School & -.3579988 & 0.004 \\
\hline Graduate Degree & 3.024647 & 0.979 \\
\hline \multicolumn{3}{|l|}{ Profession } \\
\hline Tradesman/artisan & -.7998903 & 0.034 \\
\hline \multicolumn{3}{|c|}{ Ownership of Home and Workplace } \\
\hline Owns workplace & .5287619 & 0.041 \\
\hline Owns both & .2859519 & 0.063 \\
\hline Rents workplace & .6030478 & 0.000 \\
\hline Rents both & .537942 & 0.000 \\
\hline \multicolumn{3}{|l|}{ Monthly Income } \\
\hline$(5001 \mathrm{TL}+)$ & .986048 & 0.301 \\
\hline Question 21 & 1.0638 & 0.000 \\
\hline
\end{tabular}

\begin{tabular}{|l|c|l|}
\hline & \multicolumn{2}{|c|}{6} \\
\hline Marginal Effects & \multicolumn{1}{|c|}{ Marg. } & p-val. \\
\hline Variables & -.3498724 & 0.000 \\
\hline Age & & \\
\hline $61+$ & .1691905 & 0.201 \\
\hline Marital Status & .2619388 & 0.252 \\
\hline Never Married & \\
\hline Divorced & -.40012 & 0.000 \\
\hline Widow & -.1248924 & 0.074 \\
\hline Education Level & .3060168 & 0.001 \\
\hline Primary and/or Sec -.2791146 & 0.002 \\
\hline High School & \\
\hline Graduate Degree \\
\hline Profession & .2471619 & 0.202 \\
\hline Tradesman/artisan & -.2377685 & 0.170 \\
\hline Ownership of Home and Workplace \\
\hline Owns workplace & .1552333 & 0.193 \\
\hline Owns both & .0932653 & 0.177 \\
\hline Rents workplace & .1800554 & 0.136 \\
\hline Rents both & .1771661 & 0.074 \\
\hline Monthly Income & & \\
\hline (5001 TL+) & .3689265 & 0.032 \\
\hline Question 21 & \\
\hline
\end{tabular}


Table 9

Regressions
\begin{tabular}{|l|l|l|}
\hline Q.24 & \multicolumn{2}{|c|}{7} \\
\hline Variables & Coef. & $p$-val. \\
\hline Sex & & \\
\hline Female & .3063147 & 0.017 \\
\hline Age & & \\
\hline $41-60$ & -.2087816 & 0.086 \\
\hline $61+$ & -.7095833 & 0.007 \\
\hline Marital Status & & \\
\hline Never Married & -.878427 & 0.000 \\
\hline Widow & 1,51374 & 0.000 \\
\hline Education Level & & \\
\hline Primary and/or se & -.7672391 & 0.000 \\
\hline High School & -.2198605 & 0.094 \\
\hline Ownership of home and workplace \\
\hline Owns both & .490927 & 0.002 \\
\hline Rents workplace & .4594852 & 0.006 \\
\hline Rents both & .3837839 & 0.002 \\
\hline Monthly Income & \\
\hline (1001TL-2000TL) & -.2244482 & 0.070 \\
\hline (4001-5000 TL) & .7060487 & 0.004 \\
\hline Question 24 & 1,30294 & 0.000 \\
\hline
\end{tabular}

\begin{tabular}{|l|c|l|}
\hline & \multicolumn{2}{|c|}{7} \\
\hline Marjinal Etkiler & \multicolumn{2}{|c|}{-val. } \\
\hline Variables & Marg. & $p$-ver \\
\hline Sex & .1072279 & 0.105 \\
\hline Female & & \\
\hline Age & -.071234 & 0.192 \\
\hline $41-60$ & -.267871 & 0.026 \\
\hline $61+$ & & \\
\hline Marital Status & & \\
\hline Never Married & -.3224243 & 0.002 \\
\hline Widow & .265162 & 0.305 \\
\hline Education Level & & \\
\hline Primary and/or se & -.2823341 & 0.006 \\
\hline High School & -.0738424 & 0.205 \\
\hline Ownership of home and workplace \\
\hline Owns both & .1448716 & 0.164 \\
\hline Rents workplace & .1361964 & 0.172 \\
\hline Rents both & .1233559 & 0.121 \\
\hline Monthly Income & \\
\hline (1001TL-2000TL & -.0763806 & 0.180 \\
\hline (4001-5000 TL) & .1858823 & 0.213 \\
\hline Question 24 & .4350495 & 0.057 \\
\hline
\end{tabular}

Table 10

Regressions Q.26 Variables Age $18-30$ $61+$

Marital Status

\begin{tabular}{|l|l|l}
\hline Never married & -.9730745 & 0.000
\end{tabular}

Education Level

\begin{tabular}{|l|l|l}
\hline Primary and/or se & -8194675 & 0.000
\end{tabular}

\begin{tabular}{|l|l|l|}
\hline High School & -.3910079 & 0.001 \\
\hline
\end{tabular}

\begin{tabular}{|l|r|l}
\hline Graduate Degree & 3,342668 & 0.983 \\
\hline
\end{tabular}

Ownership of Home and Workplace

\begin{tabular}{|l|l|l|}
\hline Rents workplace & .3653171 & 0.016 \\
\hline Rents both & .1976536 & 0.095 \\
\hline Monthly income & & \\
\hline (5001 TL+) & .4827483 & 0.026 \\
\hline Question 26 & .5850098 & 0.000 \\
\hline
\end{tabular}

\begin{tabular}{|l|c|c|}
\hline & \multicolumn{2}{|c|}{8} \\
\hline Marginal Effects & \multicolumn{1}{|c|}{ p-val. } \\
\hline Variables & Marg. & \\
\hline Age & & \\
\hline $18-30$ & .1017425 & 0.200 \\
\hline $61+$ & -.163707 & 0.135 \\
\hline Marital Status & & \\
\hline Never married & -.367131 & 0.000 \\
\hline Education Level & & \\
\hline Primary and/or se & -.3110791 & 0.001 \\
\hline High School & -.1394716 & 0.098 \\
\hline Graduate Degree & .323363 & 0.000 \\
\hline Ownership of Home and Workplace \\
\hline Rents workplace & .1199578 & 0.210 \\
\hline Rents both & .0690938 & 0.228 \\
\hline Monthly income & & \\
\hline (5001 TL+) & .1506072 & 0.250 \\
\hline Question 26 & .2076704 & 0.076 \\
\hline
\end{tabular}




\section{Table 11}

\begin{tabular}{|l|l|l|}
\hline Regressions & \multicolumn{2}{c}{ Model } \\
\hline Q.29 & Coef. & p-val. \\
\hline Variables & & \\
\hline Age & .320396 & 0.027 \\
\hline 61+-30 & -.8066864 & 0.002 \\
\hline Marital Status & & \\
\hline Never Married & -.830526 & 0.000 \\
\hline Education Level & & \\
\hline Primaru and/or se & -.3870133 & 0.014 \\
\hline High School & -.3174651 & 0.008 \\
\hline Graduate Degree & 3.201414 & 0.978 \\
\hline Profession & & \\
\hline Tradesman/artisan & -.9969897 & 0.008 \\
\hline Ownership of home and workplace \\
\hline Owns Workplace & .8796158 & 0.001 \\
\hline Owns Both & .3943793 & 0.012 \\
\hline Rents home & .3462642 & 0.074 \\
\hline Rents workplace & .2854122 & 0.065 \\
\hline rents both & .5359171 & 0.000 \\
\hline Monthly Income & \\
\hline (5001 TL+) & .8847896 & 0.000 \\
\hline Question 29 & 1.133813 & 0.000 \\
\hline
\end{tabular}

\begin{tabular}{|l|c|c|}
\hline & \multicolumn{2}{|c|}{9} \\
\hline Marginal Effects & \multicolumn{1}{|c|}{ M-val. } \\
\hline Variables & Marg. & \\
\hline Age & & \\
\hline $18-30$ & .1077303 & 0.131 \\
\hline $61+$ & -.3115481 & 0.002 \\
\hline Marital Status & & \\
\hline Never Married & -.3138281 & 0.000 \\
\hline Education Leve1 & & \\
\hline Primaru and/or se & -.1440995 & 0.057 \\
\hline High School & -.1132434 & 0.073 \\
\hline Graduate Degree & .3230322 & 0.000 \\
\hline Profession & & \\
\hline Tradesman/artisan & -.2927036 & 0.143 \\
\hline Ownership of home and workplace \\
\hline Owns Workplace & .233443 & 0.194 \\
\hline Owns Both & .1289995 & 0.125 \\
\hline Rents home & .1133468 & 0.179 \\
\hline Rents workplace & .0955411 & 0.167 \\
\hline rents both & .1812645 & 0.059 \\
\hline Monthly Income & \\
\hline (5001 TL+) & .2399032 & 0.178 \\
\hline Question 29 & .4025442 & 0.021 \\
\hline
\end{tabular}

Table 12

\begin{tabular}{|c|c|c|}
\hline \multicolumn{3}{|l|}{ Regressions } \\
\hline Q.30 & \multicolumn{2}{|c|}{10} \\
\hline \begin{tabular}{|l} 
Variable \\
\end{tabular} & Coef. & $p$-val. \\
\hline \multicolumn{3}{|l|}{ Age } \\
\hline $18-30$ & .3051226 & 0.036 \\
\hline $61+$ & -.7392174 & 0.004 \\
\hline \multicolumn{3}{|l|}{ Marital Status } \\
\hline Never married & -.8561308 & 0.000 \\
\hline \multicolumn{3}{|l|}{ Education Level } \\
\hline ilkokul ve/veya ortd & -.7027975 & 0.000 \\
\hline lise & -.3367907 & 0.005 \\
\hline \multicolumn{3}{|l|}{ Profession } \\
\hline Tradesman/artisan & -.9036636 & 0.015 \\
\hline \multicolumn{3}{|c|}{ Ownership of home and workplace } \\
\hline Owns both & .4247997 & 0.008 \\
\hline Rents home & .3232418 & 0.086 \\
\hline Rents both & .4387759 & 0.000 \\
\hline \multicolumn{3}{|l|}{ Monthly Income } \\
\hline (4001-5000 TL) & -.3801371 & 0.064 \\
\hline \begin{tabular}{|l}
$(5001 \mathrm{TL}+)$ \\
\end{tabular} & 1.109385 & 0.000 \\
\hline Question 30 & 1.135399 & 0.000 \\
\hline
\end{tabular}

\begin{tabular}{|l|l|l|}
\hline Rsm.Drlr.intrnt.u & \multicolumn{2}{|c|}{10} \\
\hline Marginal Effects & \multicolumn{2}{|c|}{ p-val. } \\
\hline Variable & Marg. & \\
\hline Age & & \multicolumn{1}{|c|}{} \\
\hline $18-30$ & .1023999 & 0.176 \\
\hline $61+$ & -.2853005 & 0.008 \\
\hline Marital Status & & \\
\hline Never married & -.3229155 & 0.000 \\
\hline Education Level & & \\
\hline ilkokul ve/veya ortd & -.2658171 & 0.003 \\
\hline lise & -.1196776 & 0.094 \\
\hline Profession & & \\
\hline Tradesman/artisan & -.2694559 & 0.197 \\
\hline Ownership of home and workplace \\
\hline Owns both & .1372038 & 0.168 \\
\hline Rents home & .1059185 & 0.223 \\
\hline Rents both & .149269 & 0.102 \\
\hline Monthly Income & & \\
\hline (4001-5000 TL) & -.1431437 & 0.123 \\
\hline (5001 TL+) & .2738864 & 0.268 \\
\hline Question 30 & .401466 & 0.047 \\
\hline
\end{tabular}


Table 13

Regressions
\begin{tabular}{|l|c|l|}
\hline Q.32 & \multicolumn{2}{|c|}{11} \\
\hline Variables & Coef. & p-val. \\
\hline Age & .3139804 & 0.036 \\
\hline $18-30$ & -.3924294 & 0.001 \\
\hline $41-60$ & -.7713785 & 0.000 \\
\hline Marital Status & \\
\hline Never married & & \\
\hline Education Level & -1.023618 & 0.000 \\
\hline Primary and/or se & -4863274 & 0.000 \\
\hline High school & -1.001 \\
\hline Ownership of home and workplace \\
\hline Owns both & .4023828 & 0.017 \\
\hline Rents home & .553878 & 0.008 \\
\hline Rents both & .3864667 & 0.004 \\
\hline Monthly Income & \\
\hline (5001 TL+) & 1.028167 & 0.000 \\
\hline Question 32 & 1.440279 & 0.000 \\
\hline
\end{tabular}

\begin{tabular}{|c|c|c|}
\hline \multirow[b]{2}{*}{ Marginal Effects } & \multicolumn{2}{|c|}{11} \\
\hline & & \\
\hline Variables & Marg. & $p$-val. \\
\hline \multicolumn{3}{|l|}{ Age } \\
\hline $18-30$ & .0992728 & 0.137 \\
\hline $41-60$ & -.1367774 & 0.042 \\
\hline \multicolumn{3}{|l|}{ Marital Status } \\
\hline Never married & -.2828574 & 0.002 \\
\hline \multicolumn{3}{|l|}{ Education Level } \\
\hline Primary and/or se & -.3808002 & 0.000 \\
\hline High school & -.1647233 & 0.042 \\
\hline \multicolumn{3}{|c|}{ Ownership of home and workplace } \\
\hline Owns both & .1228138 & 0.126 \\
\hline Rents home & .1585148 & 0.133 \\
\hline Rents both & .1250057 & 0.083 \\
\hline \multicolumn{3}{|l|}{ Monthly Income } \\
\hline$(5001 \mathrm{TL}+)$ & .2410674 & 0.168 \\
\hline Question 32 & .4844618 & 0.023 \\
\hline
\end{tabular}

\section{Table 14}

Model

\begin{tabular}{|l|c|c|}
\hline Regressions & \multicolumn{2}{|c}{12} \\
\hline Question 33 & Coef. & p-val. \\
\hline Variables & & \\
\hline Age & -.3664955 & 0.002 \\
\hline $61+$ & -.8158599 & 0.002 \\
\hline Marital Status & & \\
\hline Never Married & -.9778208 & 0.000 \\
\hline Education Level & & \\
\hline Primaru and/or Seco -.787378 & 0.000 \\
\hline High School & -.7136503 & 0.000 \\
\hline Graduate Degree & 2.897379 & 0.980 \\
\hline Profession & & \\
\hline Tradesman/artisan & -.7378802 & 0.070 \\
\hline Ownership of home and office & \\
\hline Owns both home and .4565652 & 0.006 \\
\hline Rents workplace & .4700267 & 0.004 \\
\hline Rents both & .3174905 & 0.012 \\
\hline Monthly Income & & \\
\hline (5001 TL+) & .8345485 & 0.001 \\
\hline Question 33 & 1.286671 & 0.000 \\
\hline
\end{tabular}

\begin{tabular}{|l|c|c|}
\hline Rsm.Drlr.intrnt. & \multicolumn{2}{|c|}{12} \\
\hline Marginal Effects & \multicolumn{2}{|c|}{ p-val. } \\
\hline Variables & Marg. & \\
\hline Age & & \\
\hline $41-60$ & -.131018 & 0.055 \\
\hline $61+$ & -.3133897 & 0.004 \\
\hline Marital Status & & \\
\hline Never Married & -.3656976 & 0.000 \\
\hline Education Leve1 & & \\
\hline Primaru and/or Se & -.2957603 & 0.002 \\
\hline High School & -.2484715 & 0.029 \\
\hline Graduate Degree & .3065359 & 0.036 \\
\hline Profession & & \\
\hline Tradesman/artisan & -.2229592 & 0.196 \\
\hline Ownership of home and office \\
\hline Owns both home a & .1429558 & 0.144 \\
\hline Rents workplace & .146043 & 0.143 \\
\hline Rents both & .1072514 & 0.115 \\
\hline Monthly Income & & \\
\hline (5001 TL+) & .2224864 & 0.199 \\
\hline Question 33 & .4468554 & 0.035 \\
\hline
\end{tabular}

